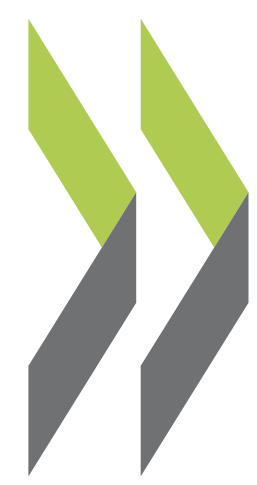

OECD Economics Department Working Papers No. 929

\title{
Less Income Inequality and More Growth - Are they Compatible? Part 6 . The Distribution of Wealth
}

Kaja Bonesmo Fredriksen 
Organisation de Coopération et de Développement Économiques

Organisation for Economic Co-operation and Development

09-Jan-2012

ECONOMICS DEPARTMENT

English - Or. English

LESS INCOME INEQUALITY AND MORE GROWTH - ARE THEY COMPATIBLE?

PART 6. THE DISTRIBUTION OF WEALTH

ECONOMICS DEPARTMENT WORKING PAPER No. 929

by Kaja Bonesmo Fredriksen

All Economics Department Working Papers are available through OECD's internet website at www.oecd.org/eco/workingpapers 


\section{ABSTRACT/RESUMÉ \\ Less income inequality and more growth - are they compatible? \\ Part 6. The distribution of wealth}

The wealth distribution within OECD countries is very concentrated and much more so than the income distribution. Wealth dispersion is especially high in the United States and Sweden. The latter illustrates that the most wealth unequal countries are not necessarily the most income unequal. Wealth inequality came down since the beginning of the $20^{\text {th }}$ century until the 1970 s, but has since been on the rise. Major explanations for this development are soaring financial markets in the aftermath of financial market deregulation in the 1970s, a lighter taxation of top incomes and wealth, which has favoured the accumulation of wealth, and the rising importance of inheritances and inter vivos gifts.

JEL classification codes: D31; D53; H23

Keywords: Net worth; wealth inequality; Luxembourg Wealth Study; inheritance; financial markets; property taxation

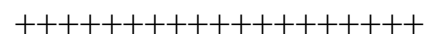

\section{Moins d'inégalités de revenu et plus de croissance - Ces deux objectifs sont-ils compatibles ? Partie 6. La répartition de la richesse}

Dans les pays de l'OCDE, la répartition de la richesse est très concentrée, bien plus encore que celle des revenus. Elle est particulièrement asymétrique aux États-Unis et en Suède. Ce dernier pays est l'exemple d'un pays où les inégalités de richesse sont fortes alors que les inégalités de revenu y sont plus faibles que dans la plupart des pays de l'OCDE. Les inégalités de richesse se sont résorbées du début du $20^{\mathrm{e}}$ siècle aux années 70 pour se creuser de nouveau depuis lors. L'essor des marchés financiers qui a fait suite à la déréglementation des marchés de capitaux dans les années 70 , l'allègement de l'imposition des plus hauts revenus et de la fortune, qui a favorisé l'accumulation de richesses, et l'importance croissante des héritages et des donations expliquent principalement cette évolution.

Classification JEL : D31 ; D53 ; H23

Mots-clés : Actif net ; inégalités de richesse ; Luxembourg Wealth Study; héritage ; marchés de capitaux ; imposition foncière 


\section{TABLE OF CONTENTS}

\section{LESS INCOME INEQUALITY AND MORE GROWTH - ARE THEY COMPATIBLE?

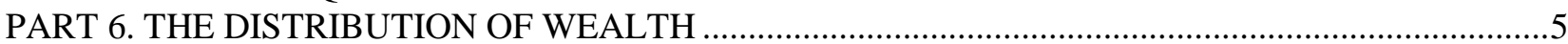

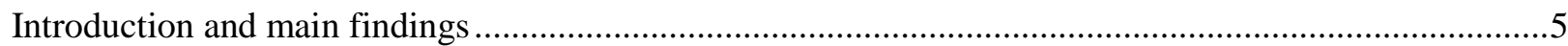

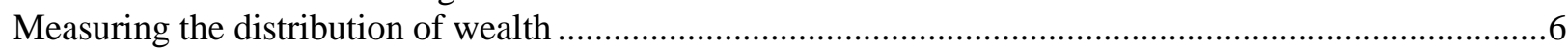

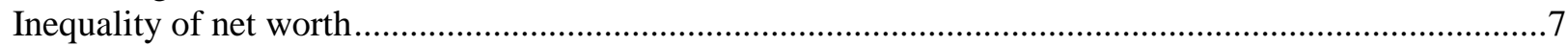

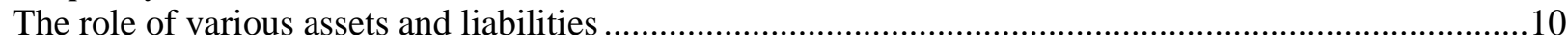

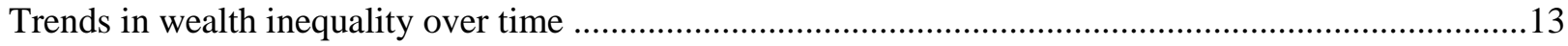

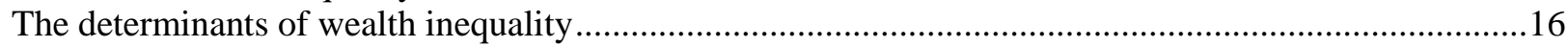

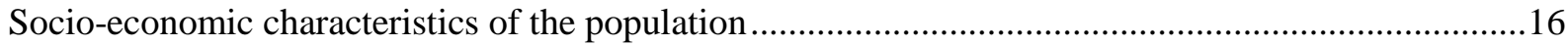

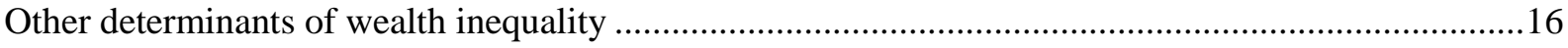

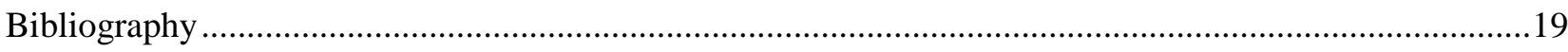

\section{Boxes}

1. Why is wealth inequality so high in Sweden?

\section{Tables}

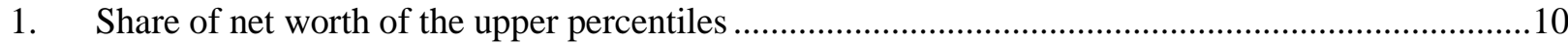

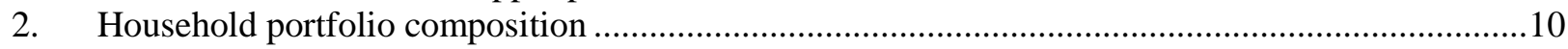

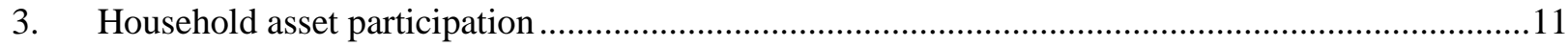

4. Gini coefficient of household net worth and its components ...................................................11

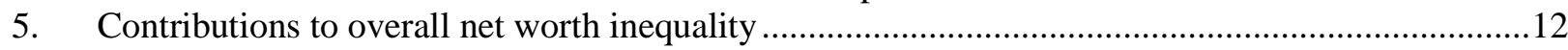

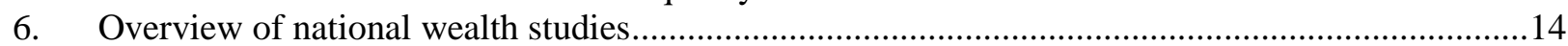

\section{Figures}

1. LWS country rankings by mean and median of net worth .......................................................

2. The share of net worth held by households at different points in the wealth distribution ..................8

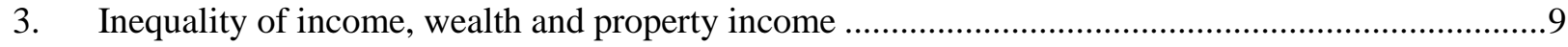

4. Median wealth holdings by age of household's head .................................................................17

This document and any map included herein are without prejudice to the status of or sovereignty over any territory, to the delimitation of international frontiers and boundaries and to the name of any territory, city or area. 
ECO/WKP(2012)6 
ECO/WKP(2012)6

\title{
LESS INCOME INEQUALITY AND MORE GROWTH - ARE THEY COMPATIBLE?
}

\section{PART 6. THE DISTRIBUTION OF WEALTH}

\author{
by Kaja Bonesmo Fredriksen ${ }^{1}$
}

\section{Introduction and main findings}

The wealth distribution is much more concentrated than the income distribution. Of the few countries for which comparable data on wealth are available, wealth inequality measured by the Gini index is highest in Sweden and the United States and relatively low in Italy. The lack of harmonised wealth data has hampered research on wealth distribution issues. This has particularly been the case for cross-country studies. The situation has recently improved with the launch of the Luxembourg Wealth Study (LWS), a harmonised household survey, which provides data on the size and composition of wealth and also includes a broad range of household characteristics for 11 OECD countries. Trends in wealth inequality can only be assessed using non-harmonised national wealth surveys. They suggest the wealth concentration came down considerably since the beginning of the $20^{\text {th }}$ century until the $1970 \mathrm{~s}$, but over the past 30 years, wealth inequality has increased again.

Section 1 of this paper reviews measurement issues. Section 2 examines the inequality of net worth whereas section 3 looks at the role of various assets and liabilities. Section 4 reviews trends in wealth inequality over time. Section 5 analyses the determinants of wealth inequality.

The main findings are:

- Wealth is very concentrated. The lowest $50 \%$ of households in the wealth distribution hold only a tiny fraction of wealth, while the top 10\% hold between $40 \%$ (Italy) and 70\% (United States) of total wealth.

- The countries with the most unequal income distribution are not necessarily those with the most unequal wealth distribution. Among the countries covered in this study, wealth inequality is particularly high in Sweden and the United States and is the lowest in Italy.

- In all countries, assets are a more important contributor to overall wealth inequality than debt. Non-financial assets contribute more than financial assets, even though financial assets are more unequally distributed in all countries. This is explained by the higher share of non-financial assets in total assets.

1. The author is seconded from the Norwegian Ministry of Finance and works at the Economics Department of the OECD. This is one of the background papers for the OECD's project on Income Distribution and Growth-enhancing Policies. The author would like to thank Jorgen Elmeskov, Peter Hoeller, Isabelle Joumard and Mauro Pisu for their useful comments and suggestions, Debra Bloch and Chantal Nicq for meticulous statistical work and Susan Gascard for excellent editorial support. 
- Wealth inequality has trended down during the $20^{\text {th }}$ century until the mid-1970s to early $1980 \mathrm{~s}$, from which point wealth inequality has been rising. The rise in inequality reflects $i$ ) soaring financial markets in the aftermath of financial market deregulation that started in the 1970s; ii) lower marginal tax rates on top incomes and lower capital gains and wealth taxation which have made the accumulation of wealth easier for the rich; iii) at least in France, inheritances and inter vivos gifts have risen again in importance over the past 30 years and stood at nearly $15 \%$ of national income in 2008 , nearly as high as a century ago.

\section{Measuring the distribution of wealth}

Wealth can be measured in different ways. Marketable wealth is the narrowest concept and includes only assets that generate capital income. Another possibility is to consider household disposable wealth which is the market value of assets minus liabilities that are directly tradable, with housing considered liquid enough to qualify. Augmented wealth is the most encompassing concept both in the time dimension, as it includes the present value of all discounted future income, and in the number of assets considered as both pension rights and human capital are also included. However, given data limitations, studies generally define wealth as household net worth, sum of household financial and non-final assets minus debt, which is the concept used here.

This implies that the value of pension rights and life insurance are excluded from the analysis. Although this is consistent with the concept of wealth as a store of value providing potential for consumption today, from a life-time perspective, assets that underpin future consumption should also be included. And not only is an important part of wealth left unaccounted for, the cross-country comparability of the data is also reduced since the omission will bias results less in countries where individuals save more for their retirement outside the public pension scheme.

Even confined to net worth, measuring wealth holdings and wealth inequality is not easy. As is always the case in distributional studies, one must rely on household survey data or tax data. Such micro data have several shortcomings mostly notably a tendency to underreport at both tails of the distribution, thereby underestimating inequality. In the case of wealth, this problem is likely to be even greater due to the highly skewed distribution. An additional problem for wealth studies has been the lack of available data to perform cross-country analyses which require harmonised definitions and a common methodology.

The Luxembourg Wealth Study launched in 2007 partly remedies this. It is a cross-country database that provides wealth data where a high degree of comparability between countries has been achieved for four financial assets (deposit accounts, bonds, stocks and mutual funds), non-financial assets (principal residence and investment in real estate) and debt. However, because of differences in the breakdown of aggregate wealth in the national surveys, there is necessarily a trade-off between the comparability of a cross-country dataset and its completeness. Currently the LWS covers only between $50 \%$ of Canadian and US household wealth and about $80 \%$ of the household wealth of the European countries. According to Jantti et al. (2008) the LWS figures provide a better coverage of non-financial assets, while coverage is lower for liabilities and lowest for financial assets. ${ }^{2}$

The country coverage of the LWS database is limited. It contains comparable data for only 11 OECD countries: Austria, Canada, Finland, Germany, Japan, Italy, Luxembourg, Norway, Sweden, the United Kingdom and the United States. Furthermore, since there are no data for non-financial assets for Austria, no debt data for Luxembourg and because property values for Norway are tax-assessed rather than market based, comparable data on net worth are not available for these three countries. In the remaining

2. In addition to pension wealth, business equity is also excluded from the data. 
countries the comparable net worth aggregate is only available in the cross-section. The LWS can therefore not be used to analyse wealth holdings over time.

\section{Inequality of net worth}

Although the percentage of households holding some assets is quite similar across countries, the value of mean and median net worth is quite different (Figure 1). Median net worth in Italy and Japan is higher than in the other countries. The United Kingdom, Finland and the United States are middling, whereas Sweden is the wealth-poorest country.

Figure 1. LWS country rankings by mean and median of net worth

In 2005 PPP USD

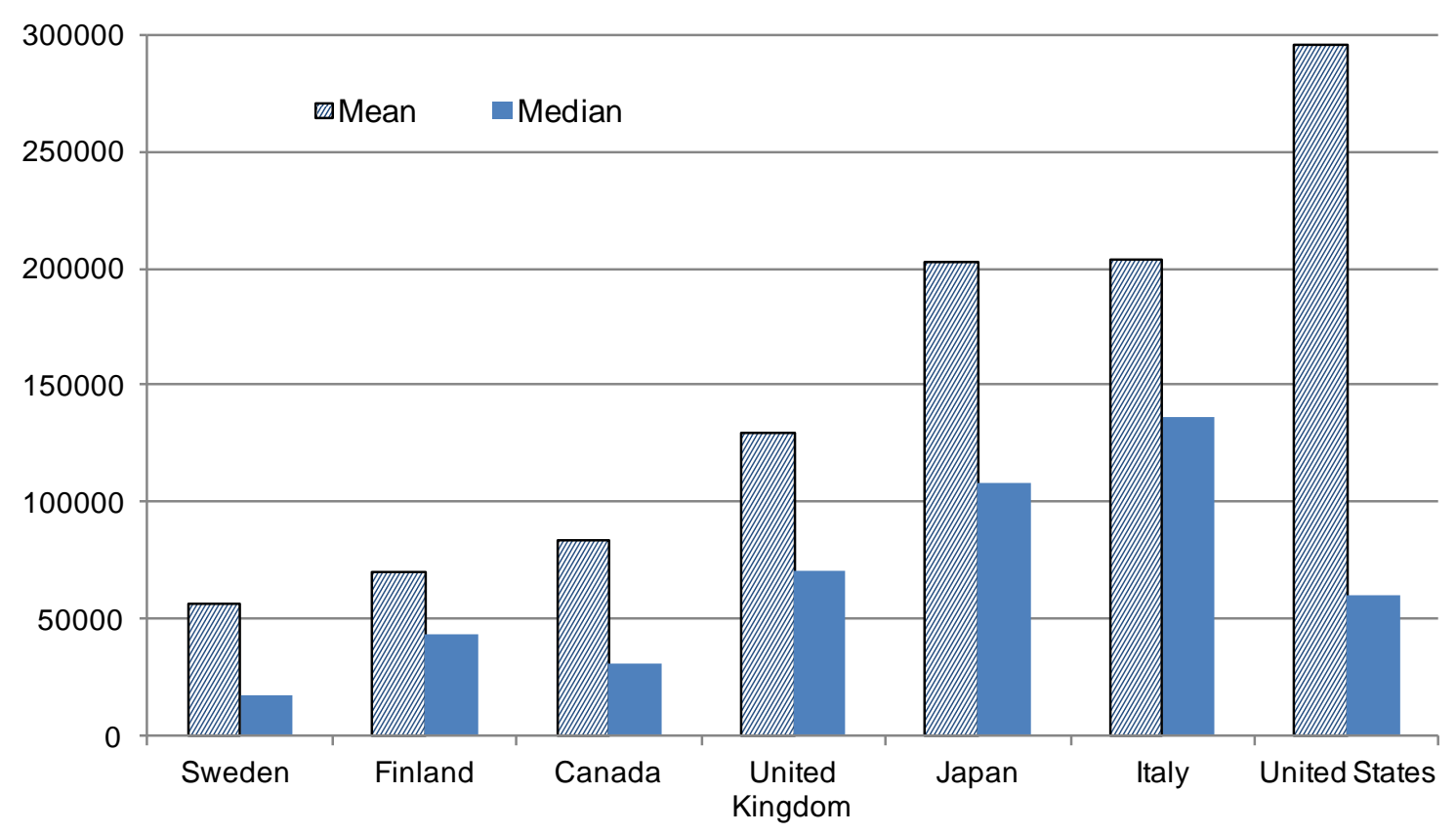

Source: Luxembourg Wealth Study.

The large cross-country differences in the ratio of mean to median net worth indicate important crosscountry differences in wealth inequality which is confirmed when looking at the share of net worth held at different points in the distribution, as well as the Gini index that measures aggregate wealth inequality (Figure 2). Wealth inequality is particularly high in Sweden (Box 1) and the United States and is the lowest in Italy. The high value for the United States could also in part reflect efforts to better capture the upper tale of the wealth distribution in the US household survey. 
Figure 2. The share of net worth held by households at different points in the wealth distribution

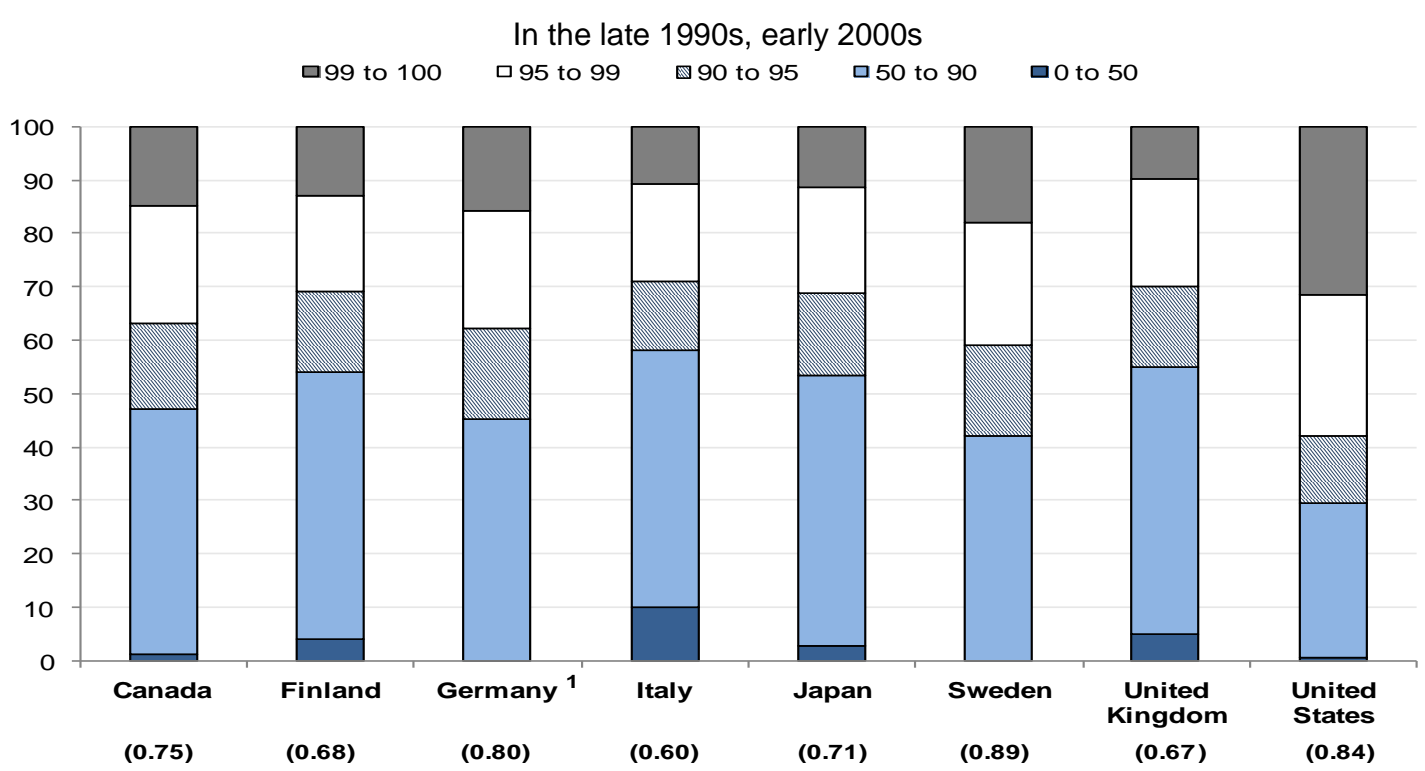

1. For Germany, the first wealth proportion refers to wealth held up to the $90^{\text {th }}$ population decile. For the United States, the Survey of Consumer Finance is used and the data refer to 2006. The Gini index for wealth is shown in brackets below the country name. Source: Luxembourg Wealth Study and OECD (2008), Growing Unequal? Income Distribution and Poverty in OECD Countries.

\section{Box 1. Why is wealth inequality so high in Sweden?}

Sweden is a particularly interesting case as inequality is very high for net worth, but very low for household disposable income. There are several potential explanations for this. Whereas in the United States the wealth distribution is very skewed at the top, Sweden is characterised by a large fraction of households with negative wealth, with the bottom $30 \%$ having negative wealth. The high incidence of debt is likely to be underpinned by interest deductibility for tax purposes, while student debt is also important. Domeij and Klein (2002) found that the generous public pension scheme with a common benefit payable to each senior citizen combined with an upper limit to benefits from the earnings-related pension scheme is a main driver of wealth inequality in Sweden as it discourages private asset accumulation at the lower end of the distribution. However, although Sweden has a relatively generous public pension scheme, it is certainly not the only country for which this is the case. Finland also has a generous welfare system, but has also relatively low wealth inequality. Finland also has a lower incidence of negative net worth and a higher home ownership rate (Davies, 2009).

Much of the difference in wealth inequality between Sweden and the other countries is caused by a more uneven distribution of non-financial wealth. First, the overall home ownership rate at $57 \%$ is low compared with most other countries. But the most striking difference with other countries is not the lower incidence, but the higher concentration of non-financial wealth. The ratio between the non-financial wealth holdings of the $75^{\text {th }}$ and the $25^{\text {th }}$ percentile is double that of the United States, and almost treble if one looks only at the primary residence. All other countries have a lower concentration of non-financial wealth, which is at least partly due to the structure of the housing market. The social rental market in Sweden is very large at $21 \%$ of the total housing stock and is almost the same size as the private rental market. The social rental market is, in addition, not that different from the private rental market. Both are quite heavily regulated with regard to prices and provide secure tenure. This makes renting more lucrative than in other countries. The generous pension system, the large rental sector and incentives to take on debt are likely to be the major reasons for the high wealth inequality in Sweden.

Wealth is much more unequally distributed than income in all countries and the countries with the most unequal income distribution are not those with the most unequal wealth distribution (Figure 3). On the other hand, both the property income concentration and that of net worth are very high in all countries. 
Figure 3. Inequality of income, wealth and property income ${ }^{1}$

A. Gini for disposable income and wealth

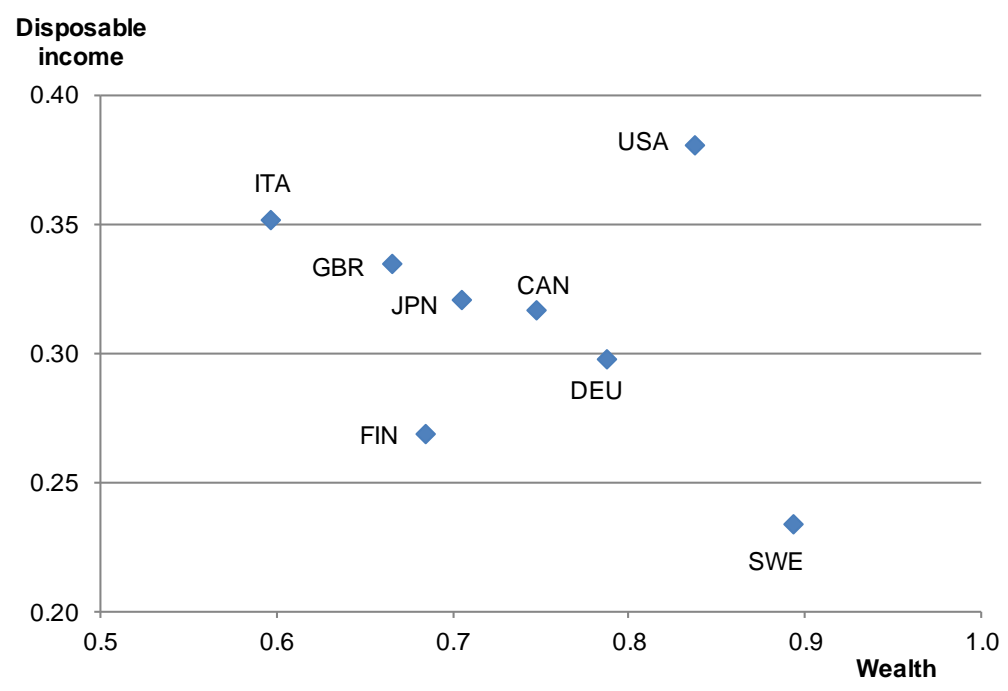

B. Gini for property income and wealth

Property income ${ }^{2}$

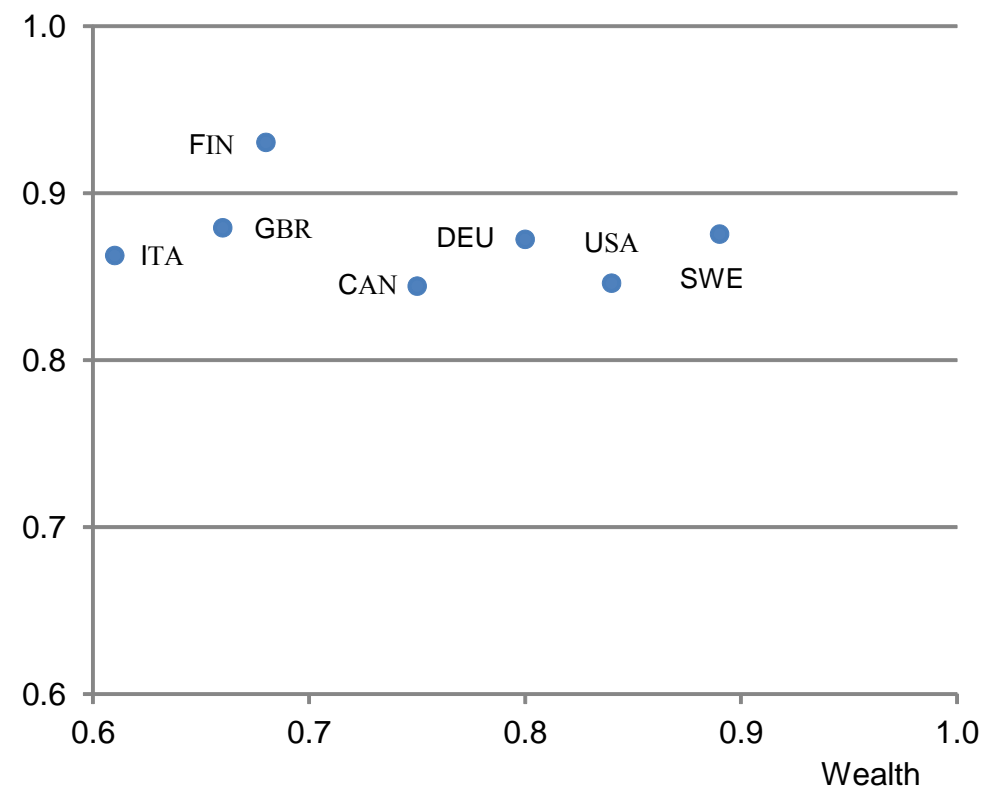

1. The income inequality data are for the mid-2000s. For wealth, the numbers refer to the following years: Canada (1999), Finland (1998), Japan (2003), Italy (2004), Sweden (2002), United Kingdom (2000) and United States (2006).

2. The property income Gini index is based on LIS data. It ranks individuals by capital income. The Gini index for wealth is based on LWS data.

Source: Luxembourg Income Study, Luxembourg Wealth Study and OECD Income Distribution and Poverty Database.

At the upper end of the wealth distribution, wealth in the United States is much more unequally distributed than in the other countries and particularly so among the very rich. The $1 \%$ wealthiest Americans hold $31 \%$ of total wealth, as compared to between $10 \%$ and $20 \%$ for the other countries (Table 1). 
Table 1. Share of net worth of the upper percentiles

\begin{tabular}{lccc}
\hline & Top 1 pct & Top 5 pct. & Top 10 pct \\
\cline { 2 - 4 } Canada & 15 & 37 & 53 \\
Finland & 13 & 31 & 46 \\
Germany & 16 & 38 & 55 \\
Italy & 11 & 29 & 42 \\
Japan & 12 & 31 & 47 \\
Sweden & 18 & 41 & 58 \\
United Kingdom $^{\text {United States }}{ }^{1}$ & 10 & 30 & 45 \\
\hline
\end{tabular}

1. The figures for the United States are based on the SCF (2006) household survey. Source: Luxembourg Wealth Study; OECD (2008), Growing Unequal? Income Distribution and Poverty in OECD Countries.

\section{The role of various assets and liabilities}

Though there are strong similarities in the relative importance and concentration of specific assets and liabilities, there are also certain notable cross-country differences. Again, these data do not account for business equity, life insurance and pension rights. Non-financial assets are more important than financial assets in all countries. Their share in total assets ranges from $87 \%$ in Germany to $71 \%$ in the United States (Table 2). Non-financial assets consist mainly of the primary residence. Although financial assets have a lower share in total assets, in terms of asset participation they are more important; in almost all countries, $75 \%$ of the population or more hold some form of financial asset (Table 3). This is mainly because most people hold some wealth in a deposit account. American households hold more financial assets relative to the households in the other countries. Furthermore, American, Swedish and Finnish households have the greatest preference for holding stocks. As regards debt holdings, there is substantial variation and the lowest level of household debt is found in Italy and the highest in Sweden.

Table 2. Household portfolio composition

Percentage share in total assets

\begin{tabular}{lcccccrrr}
\hline Wealth variable & Canada & Finland & Germany & Italy & Sweden & Japan & $\begin{array}{c}\text { United } \\
\text { Kingdom }\end{array}$ & $\begin{array}{r}\text { United } \\
\text { States }\end{array}$ \\
\hline Non-financial assets & 78 & 84 & 87 & 85 & 72 & 80 & 83 & 71 \\
Financial assets & 22 & 16 & 13 & 15 & 28 & 20 & 17 & 29 \\
Total assets & 100 & 100 & 100 & 100 & 100 & 100 & 100 & 100 \\
Debt & 26 & 16 & 23 & 4 & 35 & 18 & 21 & 25 \\
Net worth & 74 & 84 & 77 & 96 & 65 & 81 & 79 & 74 \\
\hline
\end{tabular}

1. Most of financial assets and non-housing debt are recorded only for values exceeding EUR 2500 .

2. SCF 2006.

Source: Luxembourg Wealth Study; OECD (2008), Growing Unequal? Income Distribution and Poverty in OECD Countries.

In all countries, financial assets are substantially more unequally distributed across the population than non-financial assets (Table 4). There is, however, some cross-country variation worth noting. The United States and also Canada stand out with a particularly uneven distribution of financial assets. In Canada, the difference between the distribution of financial assets and non-financial is especially large. On the other hand, the distribution of financial assets in Germany is quite even and not much more unequal than the distribution of non-financial assets. Debt is somewhat more unequally distributed than total assets in all countries except in the United States. 
Table 3. Household asset participation

In percentage

\begin{tabular}{lcccccccc}
\hline \multirow{2}{*}{ Wealth variable } & Canada & Finland & Germany & Italy & Sweden & Japan & $\begin{array}{c}\text { United } \\
\text { Kingdom }\end{array}$ & $\begin{array}{c}\text { United } \\
\text { States }\end{array}$ \\
\cline { 2 - 9 } & & & & & & & & \\
\hline Non-financial assets & 64 & 68 & 43 & 72 & 57 & 77 & 70 & 71 \\
Financial assets & 90 & 92 & 49 & 81 & 79 & 75 & 80 & 91 \\
Debt & 68 & 52 & 32 & 22 & 70 & 41 & 59 & 77 \\
\hline Non-financial assets & 64 & 68 & 43 & 72 & - & 77 & 70 & 71 \\
Financial assets & 48 & 53 & 49 & 70 & - & 71 & 58 & 64 \\
Total debt & 58 & 45 & 32 & 17 & - & 40 & 49 & 70 \\
\hline
\end{tabular}

Note: The last three columns report financial assets and debt that have been bottom-coded for all countries, so as to make them comparable with the German numbers.

1. Most financial assets and non-housing debt are recorded only for values exceeding EUR 2500 .

2. SCF 2006.

Source: Luxembourg Wealth Study; OECD (2008), Growing Unequal? Income Distribution and Poverty in OECD Countries.

Table 4. Gini coefficient of household net worth and its components

\begin{tabular}{lccccc}
\hline Gini coefficient & Net worth & Total assets & Financial assets & $\begin{array}{c}\text { Non-financial } \\
\text { assets }\end{array}$ & Debt \\
\hline Canada & 0.75 & 0.63 & 0.86 & 0.62 & 0.72 \\
Finland & 0.68 & 0.58 & 0.80 & 0.57 & 0.75 \\
Italy & 0.60 & 0.58 & 0.73 & 0.60 & 0.91 \\
Japan & 0.71 & 0.59 & 0.72 & 0.63 & 0.82 \\
Sweden & 0.89 & 0.67 & 0.78 & 0.70 & 0.73 \\
United Kingdom & 0.67 & 0.58 & 0.80 & 0.57 & 0.78 \\
United States & 0.84 & 0.74 & 0.91 & 0.70 & 0.72 \\
\hline
\end{tabular}

Source: Luxembourg Wealth Study.

How specific assets and liabilities contribute to inequality in overall net worth depends not only on their relative importance and concentration, but also how their distribution correlates with the distribution of net worth. Table 5 shows a formal decomposition of the contribution of the specific assets and liabilities to overall net worth inequality using the same method as Lerman and Yitzhaki (1985). ${ }^{3}$

In all countries, assets are a more important contributor to overall wealth inequality than debt. For most of the countries the distribution of liabilities reduces the concentration of wealth as the correlation between debt and net worth is positive, which indicates that those with high net wealth not only have more assets but also more debt. Finland and Japan are two exceptions where the correlation between debt and net worth is negative, though in the case of Finland the correlation is small.

Non-financial assets contribute more to asset inequality than financial assets despite a lower Gini index. The higher contribution of non-financial assets is explained by the higher share of non-financial wealth than financial wealth in all countries and the strong positive correlation between the concentration of non-financial wealth and total assets. The share of non-financial wealth is particularly high in Italy, whereas Americans and Swedes have the highest preference for financial assets in relative terms.

3. The Gini index of net worth (or any aggregate) can be computed as $\sum \mathrm{i} \mathrm{Gi} \times \mathrm{Ri} \times \mathrm{Si}$, where Gi is the Gini of component $\mathrm{i}, \mathrm{Ri}$ is the Gini correlation between component $\mathrm{i}$ and net worth, which varies between -1 and 1 , and $\mathrm{Si}$ is the share of component $\mathrm{i}$ in net worth. Thus, the contribution of component $\mathrm{i}$ to the Gini index of net worth can be calculated as the ratio between $(\mathrm{Gi} \times \mathrm{Ri} \times \mathrm{Si})$ and the Gini index of net worth. These contributions sum to one. 
Table 5. Contributions to overall net worth inequality

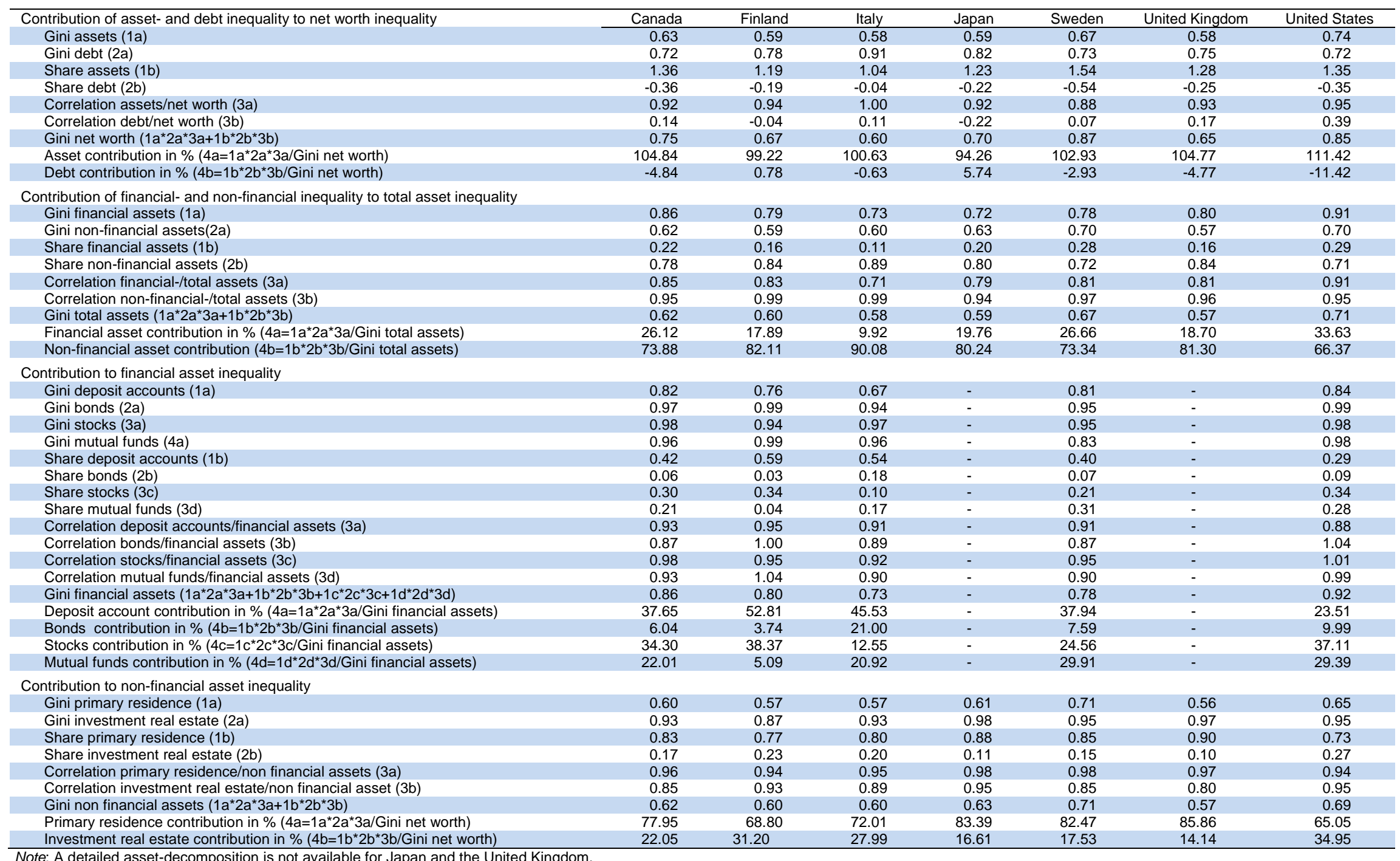

Note: A detailed asset-decomposition is not available for Japan and the United Kingdom.

Source: Luxembourg Wealth Study. 
Deposit accounts are the biggest contributor to financial asset inequality in all countries except for the United States despite the fact that they are the least unequally distributed financial asset. This is explained by the high share of deposit accounts. The contribution of stocks and mutual funds is also high in many countries, whereas bonds have a marginal impact on overall financial asset inequality. Principal residences contribute more to overall inequality in non financial assets than other real estate investment in all countries, although there is quite substantial variation in the size of the relative contributions.

\section{Trends in wealth inequality over time}

The LWS dataset is mainly cross-sectional and can therefore not be used to assess the evolution of wealth inequality over time. Tracing developments in wealth inequality for individual countries is, however, possible by relying on national surveys that have not been harmonised. This section summarises the main conclusions of, among others, Wolff (2007) and Kennickell (2003) for the United States, Morissette et al. (2003) for Canada, Klevmarken (2003) for Sweden, Brandolini et al. (2004) for Italy, Hauser et al. (2003) for Germany and Piketty et al. (2008) for France. ${ }^{4}$

National studies that rely on tax data over a long time span find that wealth inequality decreased from a very high level at the beginning of the $20^{\text {th }}$ century until the mid-1970s to early $1980 \mathrm{~s} .{ }^{5}$ Piketty et al . (2008) conclude that the decline in wealth inequality in France was mostly due to adverse shocks to the portfolios of the wealthiest in the first half of the century with wealth destruction concentrated around World War I, the stock market crash in 1929 and World War II. The enlargement of the welfare state financed by more progressive tax systems prevented a renewed sharp rise in wealth inequality after World War II. Moreover, the increase in home ownership in the United States and the United Kingdom was associated with a decline in wealth inequality (Davies, 2009).

Most studies indicate a turning point from the mid-1970s to mid-1980s, and the evidence that wealth inequality was rising at the turn of the century appears solid (Table 6). Unfortunately, more recent data on wealth inequality are sparse. Wolff $(2007,2010)$ has updated his 1983 study. He found a continued, though small, increase in total wealth inequality in the United States and a much larger increase in non-housing wealth inequality. Somewhat surprisingly, the increase was not interrupted during and in the immediate years following the burst of the dot.com bubble. This is explained by the rising indebtedness of the American middle-class, as asset inequality actually fell in the early $2000 \mathrm{~s}$.

Based on the evolution of house prices and the S\&P 500 index, Wolff (2010) estimated wealth concentration developments for recent years. According to these calculations, wealth inequality also rose during the financial crisis: by mid-2009, the wealth Gini index in the United States had reached 0.87 compared with 0.83 in 2007 . The share of total wealth captured by the richest $1 \%$ increased from $35 \%$ to $37 \%$ and that of the 5\% richest increased from $62 \%$ to $65 \%$. At the other end of the wealth distribution there was a sharp increase in the number of households with zero or negative wealth.

4. The study by Piketty covers estate data based on tax files over a very long period. The estate tax covers nearly all types of property included in the LWS definition of financial and non-financial wealth except for government bonds until 1850. Liabilities are however not subtracted from the "estate" making the measure of wealth different from the other studies looking at net worth.

5. In 1920, the $1 \%$ wealthiest Swedes held $50 \%$ of total wealth and in 1975 this share had declined to $21 \%$. In England and Wales their share declined from $61 \%$ in 1923 to $23 \%$ in 1981, whereas in the United States their share declined from $37 \%$ in 1922 to $17 \%$ in 1976 (Davies and Shorrocks, 2000). 


\begin{tabular}{|c|c|c|c|c|c|}
\hline Study & Country & Time span & $\begin{array}{l}\text { Overall trend in } \\
\text { wealth inequality }\end{array}$ & Results & Explanations \\
\hline $\begin{array}{l}\text { Morisette et al. (2003), "The } \\
\text { Evolution of Wealth } \\
\text { Inequality in Canada, } \\
\text { 1984-1999" }\end{array}$ & Canada & $\begin{array}{l}\text { Household surveys } 1984 \\
\text { and } 1999\end{array}$ & Increasing inequality & $\begin{array}{l}\text { Only those located in the } 2 \text { upper deciles have } \\
\text { increased their share in total wealth. Median } \\
\text { wealth fell in p0-p30, and rose } 27 \% \text { or more in } \\
\text { p70-p } 100 \text {. Increase in the wealth Gini index of } \\
4 \%-8 \% \text {. Increase in the coefficient of variation } \\
\text { of } 35 \% \text {. Inequality among non-elderly couples } \\
\text { with children increased the most. Older } \\
\text { households have become relatively richer. } \\
\text { Growing proportion of young couples with } \\
\text { children with } 0 \text { or negative wealth. }\end{array}$ & $\begin{array}{l}\text { Population ageing has decreased wealth } \\
\text { inequality. Other socio-economic factors } \\
\text { such as permanent income and other } \\
\text { family attributes are not important } \\
\text { explanatory factors. Most of the rise in } \\
\text { wealth inequality can be explained by } \\
\text { growing inheritances, inter vivos } \\
\text { transfers and the evolution of relative } \\
\text { returns on savings. }\end{array}$ \\
\hline $\begin{array}{l}\text { Jantti (2003), "Trends in the } \\
\text { Distribution of Income and } \\
\text { Wealth: Finland, 1987-98" }\end{array}$ & Finland & $\begin{array}{l}\text { Household wealth } \\
\text { surveys in 1988, } 1994 \\
\text { and } 1998\end{array}$ & Increasing inequality & $\begin{array}{l}\text { Gini net worth was } 55.1 \text { in } 1987,60.4 \text { in } \\
1994 \text { and } 61.5 \text { in } 1998 . \text { The dispersion of } \\
\text { assets occurred mostly in the late } 1990 \mathrm{~s} \text {, } \\
\text { whereas that of debt occurred earlier. }\end{array}$ & $\begin{array}{l}\text { Socio-demographic factors have only } \\
\text { minor explanatory power. Increases in } \\
\text { income and wealth inequality seem to } \\
\text { stem from same phenomenon. One } \\
\text { possible explanation is increased } \\
\text { inequality of property and/or property } \\
\text { income. }\end{array}$ \\
\hline $\begin{array}{l}\text { Hauser et al. (2003), } \\
\text { "Inequality of the } \\
\text { Distribution of Personal } \\
\text { Wealth in Germany } \\
\text { 1973-1998" }\end{array}$ & Germany & $\begin{array}{l}\text { Household surveys } \\
\text { 1973-98 }\end{array}$ & $\begin{array}{l}\text { Slight decrease in } \\
\text { inequality in West- } \\
\text { Germany from } \\
\text { 1973-93. Increase } \\
\text { from 1993-98 }\end{array}$ & $\begin{array}{l}\text { Decreasing inequality of net housing wealth } \\
\text { from } 1983-1993, \text { then rising trend. Inequality } \\
\text { of net financial wealth fluctuated over the } \\
\text { period. }\end{array}$ & $\begin{array}{l}\text { It appears that inheritance and inter vivo } \\
\text { gifts play an important role and } \\
\text { increasing wealth inequality is expected } \\
\text { in the future because of the following: } \\
\text { Retrenched welfare state, reduced social } \\
\text { transfers and larger inheritances. }\end{array}$ \\
\hline $\begin{array}{l}\text { Brandolini et al. (2004), } \\
\text { "Household Wealth } \\
\text { Distribution in Italy in the } \\
\text { 1990s" }\end{array}$ & Italy & $\begin{array}{l}\text { Household surveys for } \\
1989,1991,1993,1995, \\
1998 \text { and } 2000\end{array}$ & $\begin{array}{l}\text { Slightly decreasing } \\
\text { inequality from } \\
\text { 1989-91, then } \\
\text { increasing inequality }\end{array}$ & $\begin{array}{l}\text { The Gini index was } 0.55 \text { in } 1989,0.54 \text { in } \\
1991 \text { and } 0.61 \text { in } 2000 \text {. The richest } 5 \% \text { had } \\
\text { increased their share of the total by } 9.1 \mathrm{pp} \text {. } \\
\text { in } 2000 \text {. Also older households increased } \\
\text { their share of total wealth. }\end{array}$ & $\begin{array}{l}\text { Increased concentration in financial } \\
\text { wealth. Changes in demographic } \\
\text { characteristics contributed only } \\
\text { marginally to higher inequality. Increase } \\
\text { in the proportion of holders of risky } \\
\text { assets amplified the increasing trend in } \\
\text { inequality. }\end{array}$ \\
\hline $\begin{array}{l}\text { Klevmarken (2001), "On the } \\
\text { Wealth Dynamics of } \\
\text { Swedish Families } \\
\text { 1984-1998" }\end{array}$ & Sweden & $\begin{array}{l}\text { Household surveys for } \\
1984,1986,1993,1996 \\
\text { and } 1998\end{array}$ & Increasing inequality & $\begin{array}{l}\text { Small increase in the net worth of the 10th } \\
\text { percentile. Larger increase in median net } \\
\text { worth. Largest increase in net worth in the } \\
\text { 90th percentile. }\end{array}$ & $\begin{array}{l}\text { Peak of the age-earnings profile of the } \\
\text { baby-boom generation. Increasing } \\
\text { distrust in the social security system. } \\
\text { Increased private savings to } \\
\text { compensate expected cut in public } \\
\text { pensions. Increased stock prices to } \\
\text { housing prices ratio. }\end{array}$ \\
\hline
\end{tabular}


Table 6. Overview of national wealth studies, continued

\begin{tabular}{|c|c|c|c|c|c|}
\hline Study & Country & Time span & $\begin{array}{c}\text { Overall trend in } \\
\text { wealth inequality }\end{array}$ & Results & Explanations \\
\hline $\begin{array}{l}\text { Klevmarken (2003), "On } \\
\text { Household Wealth Trends } \\
\text { in Sweden over the 1990s" }\end{array}$ & Sweden & 1990s & Increasing inequality & $\begin{array}{l}\text { During the } 1980 \text { s and } 1990 \text { s real median } \\
\text { wealth increased by approximately } 30 \% \text {. The } \\
\text { increase for the top decile was } 50 \% \text { whereas } \\
\text { there was no increase for the left tail of the } \\
\text { distribution. }\end{array}$ & $\begin{array}{l}\text { Concerns about the viability of the public } \\
\text { pension system have increased private } \\
\text { life-cycle savings. Deregulation of } \\
\text { financial markets. Tax reform. } \\
\text { Demographic changes. }\end{array}$ \\
\hline $\begin{array}{l}\text { Ambrosio and Wolff (2001), } \\
\text { "Is Wealth Becoming More } \\
\text { Polarized in the United } \\
\text { States?" }\end{array}$ & $\begin{array}{l}\text { United } \\
\text { States }\end{array}$ & $\begin{array}{l}\text { Household surveys } \\
\text { (SCF) for } 1983,1989, \\
1992,1995 \text { and } 1998\end{array}$ & $\begin{array}{l}\text { Steeply increasing } \\
\text { inequality from 1983-89, } \\
\text { then increase but at a } \\
\text { much slower pace from } \\
1989\end{array}$ & $\begin{array}{l}\text { Period } 1983-89 \text { : Wealth Gini increased from } \\
0.80 \text { to } 0.83 \text {. Share of top percentile } \\
\text { increased by } 3.6 \mathrm{pp} \text {. Period } 1989-98 \text { : Wealth } \\
\text { Gini decreased from } 0.83 \text { to } 0.82 \text {. Share of } \\
\text { top percentile increased by } 0.7 \mathrm{pp} \text {. }\end{array}$ & $\begin{array}{l}\text { Most of the increased wealth inequality } \\
\text { is due to increased within-group } \\
\text { inequality. Changes in socio- } \\
\text { demographic factors do not explain } \\
\text { much. }\end{array}$ \\
\hline $\begin{array}{l}\text { Kennickell (2003), "A } \\
\text { Rolling Tide: Changes in } \\
\text { the Distribution of Wealth in } \\
\text { the U.S., 1989-2001" }\end{array}$ & $\begin{array}{l}\text { United } \\
\text { States }\end{array}$ & $\begin{array}{l}\text { Household surveys } \\
\text { (SCF) and Forbes data } \\
\text { on the } 400 \text { wealthiest } \\
\text { Americans over the } \\
\text { period } 1989-2001\end{array}$ & $\begin{array}{l}\text { Strongest growth in } \\
\text { wealth at the top and } \\
\text { bottom of the } \\
\text { distribution. Fairly } \\
\text { even growth in the } \\
\text { middle, though simple } \\
\text { concentration } \\
\text { measures fail to show } \\
\text { consist patterns }\end{array}$ & $\begin{array}{l}\text { Forbes data: Overall mean wealth of the } \\
\text { group fairly flat. Substantial growth in the } \\
\text { wealth of the top } 50 \text { persons. Substantial } \\
\text { amount of churning. Household survey: } \\
\text { Share of the bottom half of the distribution } \\
\text { approximately unchanged, decrease in the } \\
\text { share of p50-p90. Quite large increases in } \\
\text { the share of p90-p100. }\end{array}$ & \\
\hline $\begin{array}{l}\text { Wolff (2007), "Recent } \\
\text { Trends in Household } \\
\text { Wealth in the United States: } \\
\text { Rising Debt and the Middle- } \\
\text { Class Squeeze" and } \\
\text { Wollf (2010), "Recent } \\
\text { Trends in Household } \\
\text { Wealth in the United States: } \\
\text { Rising Debt and the Middle- } \\
\text { Class Squeeze - an Update } \\
\text { to 2007" }\end{array}$ & $\begin{array}{l}\text { United } \\
\text { States }\end{array}$ & $\begin{array}{l}\text { Household survey (SCF) } \\
1983,1989,1992,1995, \\
1998,2001,2004 \text { and } \\
2007\end{array}$ & $\begin{array}{l}\text { Sharply increasing } \\
\text { inequality from } \\
\text { 1983-89. Very modest } \\
\text { increase from 1989- } \\
\text { 98. Modest increase in } \\
\text { inequality in the } \\
\text { 2000s. }\end{array}$ & $\begin{array}{l}\text { Gini wealth was } 0.80 \text { in } 1983,0.83 \text { in } 1989 \text {, } \\
0.829 \text { in } 2004 \text { and } 0.834 \text { in } 2007 \text {. Share of } \\
\text { top percentile increased from } 33.8 \% \text { to } \\
34.6 \% \text {, but peaked in } 1998 \text {. Share of the top } \\
\text { quintile increased over the entire period from } \\
81.3 \% \text { to } 85 \% \text {. Shift in wealth from younger } \\
\text { to older households. }\end{array}$ & $\begin{array}{l}\text { Relative asset prices (surge in stock } \\
\text { prices over the period). Increasing } \\
\text { indebtedness of the middle class for the } \\
\text { last period (2000-04) during which there } \\
\text { was actually a decline in asset } \\
\text { inequality. }\end{array}$ \\
\hline
\end{tabular}




\section{The determinants of wealth inequality}

Apart from the distribution of market income, differences in the value of wealth holdings and wealth inequality are likely to be influenced by socio-demographic characteristics of households, inheritance patterns, the composition of wealth portfolios and the evolution of relative returns on assets.

\section{Socio-economic characteristics of the population}

Age, education and family type are all variables one would expect to be correlated both with the income and wealth distribution. According to the life-cycle theory, wealth holdings by age should follow a hump-shaped profile where net worth increases until an age close to retirement, and decreases thereafter (in its strictest form, down to zero). Using LWS data, one finds indeed evidence of steadily increasing net worth until the age of 65 years. However, dis-saving during retirement is limited in most countries and does not occur in the United States and Canada (Figure 4). A hump-shaped profile is even less visible for financial assets, with a continuing strong increase in financial wealth holdings in the United States and Canada until a late age. On the other hand, a clear hump-shaped age profile can be seen for indebtedness, a result confirmed by national surveys.

A notable exception from these general patterns is Australia. According to Bradbury (2008), Australian income and home ownership patterns in retirement are very different from other countries as income decreases sharply, whereas housing wealth remains high. He argues that at least part of the explanation for this phenomenon is that public pensions are means-tested against income and assets excluding housing.

Some of the national studies find evidence that socio-demographic factors have played a role in shaping wealth inequality over time (Table 6), but this has mainly been due to an age effect. Changes in other socio-demographic characteristics seem to have mattered little. Almas and Mogstad (2010) who developed a new age-adjusted Gini indicator found no difference in country rankings compared to the ordinary Gini index, suggesting that age is not an important factor behind the observed country differences in wealth inequality.

\section{Other determinants of wealth inequality}

Overall the studies tend to favour macroeconomic factors to explain increasing wealth inequality over the past 30 years. Both returns on assets and the tax treatment vary across assets and higher yielding financial assets are a much more important part of wealth holdings at the upper end of the distribution. In contrast, the share of deposit accounts, principal residences and related mortgages are more important in the middle and lower parts of the distribution. 
ECO/WKP(2012)6

Figure 4. Median wealth holdings by age of household's head

2002 US dollars

\begin{tabular}{|c|c|c|}
\hline$\longrightarrow$ Canada & $\longrightarrow$ Finland & $\longrightarrow$ Germany (1) \\
\hline 1 Sweden & ---- United Kingdom & $\leadsto$ United States (SCF) \\
\hline
\end{tabular}

\section{Net worth}

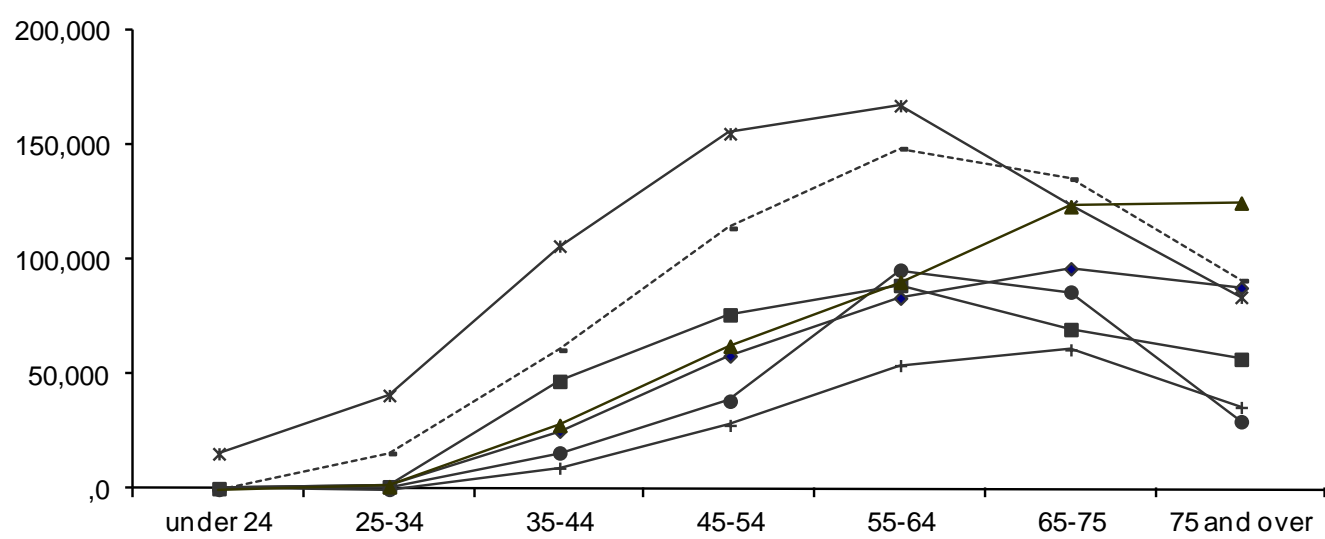

Financial assets

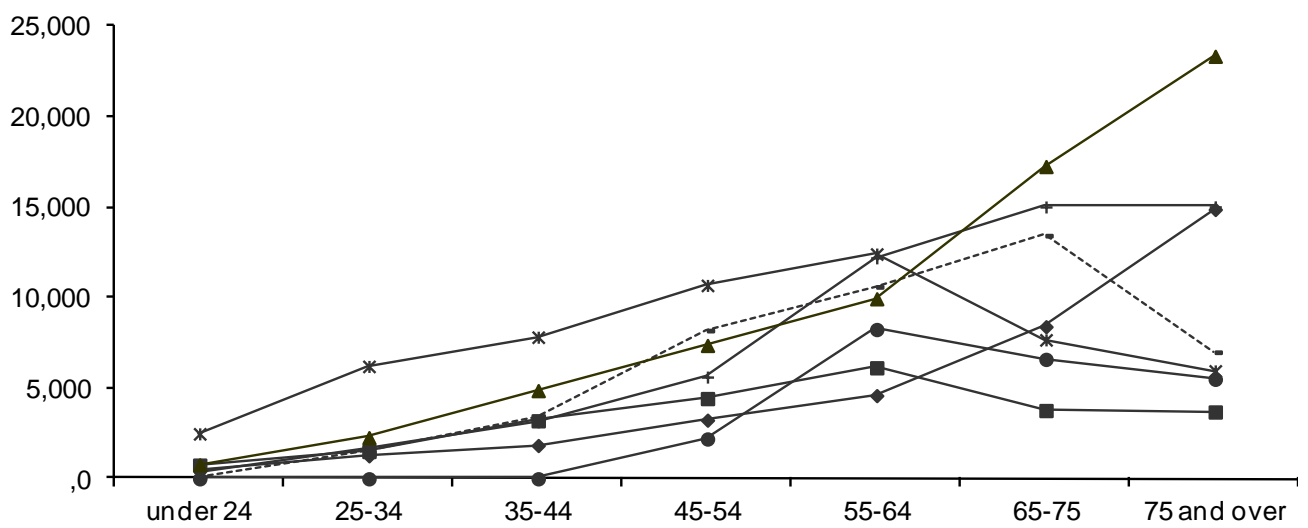

Debt

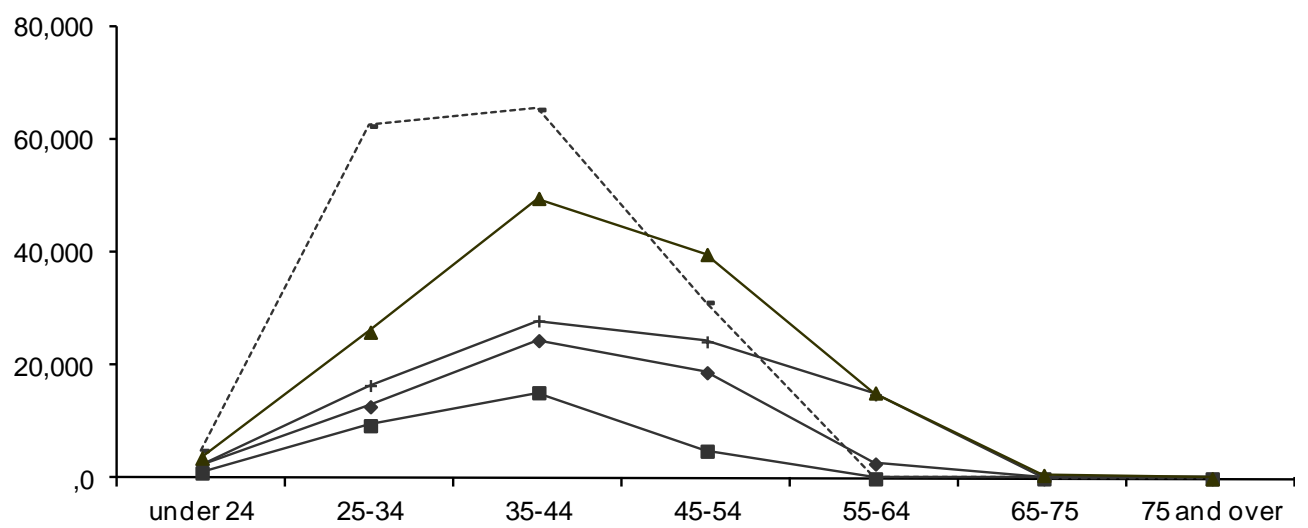

1. In Germany, financial assets and non-housing debt are recorded for values of EUR 2500 or more.

Note: Data based on household weights.

Source: Jantti, M., E. Sierminska and T. Smeeding (2008). "The Joint Distribution of Household Income and Wealth: Evidence from the Luxembourg Wealth Study", OECD Social, Employment and Migration Working Paper, No. 65. 
Soaring financial markets in the aftermath of financial deregulation during the 1970s and particularly the stock market boom in the late 1990s is consistent with greater wealth concentration at the top. Wolff (2002) finds that wealth inequality is positively related to the ratio of stock prices to house prices. For Canada, Morisette et al. (2003) also conclude that the rates of return on assets are an important factor in explaining wealth inequality over time.

Changes in tax and transfer systems are also likely to have affected wealth accumulation and distribution. Lower top marginal tax rates and lighter capital gains taxation in many countries make the accumulation of wealth easier for the rich. Klevmarken (2003), for instance, notes that the Swedish tax reform at the beginning of the 1990s that increased the return on financial assets contributed to increased wealth inequality. However, there has also been increased targeting of transfers, especially in the Englishspeaking countries, which are clawed back by tax systems as income rises, while some countries also apply asset tests. Taken in isolation this should have improved the income position of the poor, increasing their chances to accumulate wealth, though asset-testing public transfers will also have a direct discouraging effect on savings (Davies, 2009).

An interesting feature of the German national wealth study is that it compares wealth inequality between East and West-Germany, and looks specifically at the effect of reunification. Thus, a "natural experiment" is exploited to look at the effect on the wealth distribution of passing from a socialist system to a market economy. At the time of reunification, the average West-German household was much wealthier than the average East-German household. However, surprisingly, the authors find that although income was more unequally distributed in West-Germany, the reverse was true for wealth. Moreover, after reunification, wealth inequality has evolved differently, increasing in West-Germany while decreasing in East-Germany.

Finally, wealth accumulation and distribution depends on inheritance patterns. On average, over the period 1989-2007, 20.9\% of American households received a wealth transfer and all wealth transfers received made up 23.2\% of net worth (Wolff and Gittleman, 2011). These results are close to a number of other studies for the United States, and also an estimated share of inherited wealth in Sweden in 1998 of $19 \%$ (Klevmarken, 2001). ${ }^{6}$ Inheritance appears to play a bigger role in wealth accumulation in France where inherited wealth was estimated at 35\% of total wealth in 1975 (Kessler and Masson 1979, 1989). Using French tax data assembled since the beginning of the $18^{\text {th }}$ century, Piketty (2010) found that annual inheritance flows in France were around 15\% of national income in 2010.

Wealth transfers are very concentrated, and, at least in the case of United States, even more so than total wealth. In 1998, the Gini index for wealth transfers was 0.96 (Wolff and Gittleman, 2011). Using the French "Mutations à titre gratuit" surveys conducted in 1987 and 1994, Arrondel et al. (2001) found that $42 \%$ of bequests were made by the top decile and $13 \%$ by the top centile. Adding inter-vivos gifts made until 10 years before death increases the concentration of inheritance even further.

Comparing the socio-economic characteristics of heirs versus non-heirs confirms that not only are wealth transfers concentrated on a few lucky recipients, but those who benefit are individuals already favoured in life. For the United States, Wolff and Gittleman (2011) found an increasing share of recipients as one moves up both in the income and wealth distribution. The likelihood of receiving a bequest also increases with education and for those with a white ethnic origin.

6. The same study found that $35 \%$ of households received a wealth transfer in 1998 . 
ECO/WKP(2012)6

\section{Bibliography}

Almaas, I. and M. Mongstad (2010), "Older or Wealthier? The Impact of Age-Adjustment on CrossSectional Inequality Measures", Norwegian School of Economics and Business Administration Department of Economics Discussion Paper Series.

Arrondel, L. and A. Laferrere (2001), "Taxation and Wealth Transmission in France", Journal of Public Economics, Vol. 79.

Bager-Sjogren, L. and N.A. Klevmarken (1993), "The Distribution of Wealth in Sweden 1984-86", in Research in Economic Inequality, Vol. 4.

Bradbury, B. (2008), "Housing Wealth as Retirement Saving: Does the Australian Model Lead to Over-Consumption of Housing?", LWS Working Paper Series, No. 7.

Brandolini, A., L. Cannari, G. D'Alessio and I. Faiella (2004), "Household Wealth Distribution in Italy in the 1990s", Levy Economics Institute Working Paper, No. 414.

Davies, J. and A. Shorrocks (2000), "The Distribution of Wealth", in A.B. Atkinson and F. Bourguignon (eds.), Handbook of Income Distribution.

Davies, J.B. (2009), "Wealth and Inequality", in: Salverda, W., B. Nolan and T. Smeeding (eds.), The Oxford Handbook of Economic Inequality, Oxford University Press.

Domeij, D. and P. Klein (2002), "Public Pensions: To what Extent Do They Account for Swedish Wealth Inequality?", Review of Economic Dynamics, No. 5.

Frick, J. and M. Grabka (2010), "Wealth Inequality and the Importance of Public Pension Entitlements", paper prepared for the LIS conference on Inequality and the Status of the Middle Class: Lessons from the Luxembourg Income Study, Luxembourg, 29-30 June 2010.

Hauser, R. and S. Holger (2003), "Inequality of the Distribution of Personal Wealth in Germany 1973-1998”, Levy Economics Institute Working Paper, No. 398.

Jantti, M., E. Sierminska and T. Smeeding (2008), "The Joint Distribution of Household Income and Wealth: Evidence from the Wealth Study", OECD Social, Employment and Migration Working Paper, No. 65, OECD Publishing.

Kennickell, A. (2003), "A Rolling Tide: Changes in the Distribution of Wealth in the US, 1989-2001", paper presented at the Levy Institute Conference on International Perspectives on Household Wealth, October 2003.

Klevmarken, N.A. (2003), "On Household Wealth Trends in Sweden over the 1990s", Department of Economics, Uppsala University. 
ECO/WKP(2012)6

Maunu, T. (2010) “The Distribution of Pension Wealth in Finland", Finnish Centre for Pensions Working Papers, No. 3.

Morisette, R., X. Zhang and M. Drolet, (2003), "The Evolution of Wealth Inequality in Canada, 1984-1999”, Levy Economics Institute Working Paper, No. 369.

OECD (2008), Growing Unequal? Income Distribution and Poverty in OECD Countries, OECD Publishing.

Piketty, T. (2010), “On the Long-Run Evolution of Inheritance: France 1820-2050”, Paris School of Economics.

Piketty, T., G. Postel-Vinay and J-L. Rosenthal (2006), "Wealth Concentration in a Developing Economy: Paris and France, 1807-1994", American Economic Review, Vol. 96, No. 1.

Piketty, T., G. Postel-Vinay and J-L. Rosenthal (2010), "Inherited vs. Self-Made Wealth: Theory and Evidence from a Rentier Society", mimeo.

Spånt, R. (1981), "The Development of the Distribution of Wealth in Sweden”, Review of Income and Wealth, Vol. 27, No. 1.

Wolff, E. (2007), "Recent Trends in Household Wealth in the United States: Rising Debt and the MiddleClass Squeeze", Levy Economics Institute Working Paper, No. 502.

Wolff, E. (2010), "Recent Trends in Household Wealth in the United States: Rising Debt and the MiddleClass Squeeze - An Update to 2007”, Levy Economics Institute Working Paper, No. 589.

Wolff, E. (2011), “Pensions in the 2000s: The Lost Decade?”, NBER Working Paper, No. 16991. 


\section{WORKING PAPERS}

The full series of Economics Department Working Papers can be consulted at www.oecd.org/eco/workingpapers/

928. Less income inequality and more growth - Are they compatible?

Part 5. Poverty in OECD countries

(January 2012) by Mauro Pisu

927. Less income inequality and more growth - Are they compatible?

Part 4. Top incomes

(January 2012) by Peter Hoeller

926. Less income inequality and more growth-Are they compatible?

Part 3. Income redistribution via taxes and transfers across OECD countries

(January 2012) by Isabelle Joumard, Mauro Pisu and Debbie Bloch

925. Less income inequality and more growth-Are they compatible?

Part 2. The distribution of labour income

(January 2012) by Isabell Koske, Jean-Marc Fournier and Isabelle Wanner

924. Less income inequality and more growth-Are they compatible?

Part 1. Mapping income inequality across the OECD

(January 2012) by Peter Hoeller, Isabelle Joumard, Mauro Pisu and Debbie Bloch

923. Current issues in managing government debt and assets

(December 2011) by Eckhard Wurzel and Lukasz Rawdanowicz

922. Public spending efficiency in the Czech Republic: fiscal policy framework and the main spending areas of pensions and healthcare

(December 2011) by Zuzana Smidova

921. Exploring determinants of subjective wellbeing in OECD countries - evidence from the World Value Survey

(December 2011) by Sarah Fleche, Conal Smith and Piritta Sorsa

920. Russia: progress in structural reform and framework conditions

(December 2011) by Yana Vaziakova, Geoff Barnard and Tatiana Lysenko

919. Explaining the interest-rate-growth differential underlying government debt dynamics

(December 2011) by David Turner and Francesca Spinelli

918. Reassessing the NAIRUs after the crisis

(December 2011) by Stéphanie Guichard and Elena Rusticelli

917. Employment protection legislation and plant-level productivity in India

(December 2011) by Sean Dougherty, Verónica Frisancho Robles and Kala Krishna

916. Systemically important banks and capital regulation challenge

(December 2011) by Patrick Slovik 
915. Improving educational outcomes in Slovenia

(December 2011) by Mehmet Eris

914. Addressing challenges in the energy sector in Israel

(December 2011) by Philip Hemmings

913. Issues in private sector finance in Israel

(December 2011) by Philip Hemmings

912. How to improve the economic policy framework for the housing market in Israel

(December 2011) by Philip Hemmings

911. Fiscal Prospects and Reforms in India

(December 2011) by Richard Herd, Sam Hill and Vincent Koen

910. Structural reforms to reduce unemployment and restore competitiveness in Ireland

(December 2011) by Álvaro Pina

909. Getting back on track: restoring fiscal sustainability in Ireland

(December 2011) by David Haugh

908. A welfare analysis of climate change mitigation policies

(November 2011) by Alain de Serres and Fabrice Murtin

907. Overcoming the banking crisis in Ireland

(November 2011) by Muge Adalet McGowan

906. Macroeconomic and structural policies to further stabilise the Mexican economy

(November 2011) by Cyrille Schwellnus

905. Reaping the benefits of a transition to greener growth in Slovakia

(November 2011) by Caroline Klein

904. Fiscal reform for a stronger fairer and cleaner Mexican economy

(October 2011) by Nicola Brandt and Rodrigo Paillacar

903. The demand for safe assets in emerging economies and global unbalances: new empirical evidence (October 2011) by Rudiger Ahrend and Cyrille Schwellnus

902. Drivers of systemic banking crises: the role of bank-balance-sheet contagion and financial account structure

(October 2011) by Rudiger Ahrend and Antoine Goujard

901. Explaining the appreciation of the Brazilian Real

(October 2011) by Annabelle Mourougane

900. Raising investment in Brazil

(October 2011) by Jens Arnold

899. Refining macroeconomic policies to sustain growth in Brazil

(October 2011) by Annabelle Mourougane 